\title{
MENINGKATKAN KESADARAN MASYARAKAT MENGENAI PENTINGNYA MENERAPKAN PROTOKOL KESEHATAN SEBAGAI UPAYA MEMUTUS MATA RANTAI PENYEBARAN COVID-19 DI KELURAHAN CIPUTAT
}

\author{
Ani Meryati, Muhamad Nurhamdi, Siti Aprilliani, Dede Abdurohman, Sawukir \\ Universitas Pamulang \\ dosen02484@unpam.ac.id, dosen02483@unpam.ac.id, dosen02494@unpam.ac.id dan \\ dosen02402@unpam.ac.id, dosen02319@unpam.ac.id
}

\begin{abstract}
This community service activity aims to socialize and provide education about the importance of implementing health protocols as an effort to break the chain of the spread of Covid-19. The method used is in the form of counseling and providing information about the importance of implementing health protocols and clean living habits by diligently washing hands with soap, using masks when on activities outside the home, and maintaining a safe distance when in public places. This activity was held in the Hall of Ciputat Village, Jalan Ki Hadjar Dewantara no. 7 Rt. 001/006, Ciputat, Tangerang Selatan. The results show that after the implementation of this activity the participants from the Ciputat village became increasingly aware of the importance of implementing good health protocols regarding how to wash hands and use the correct masks and a safe distance to avoid covid transmission. -19. However, the awareness of the surrounding community regarding the importance of implementing health protocols is still lacking, especially regarding maintaining a safe distance. Besides, community mobility is still difficult to control, both for work and just going out of the house. With this socialization, it is hoped that participants with their authority as village officials can pass on their knowledge and understanding to the community, especially the residents of Ciputat Village.
\end{abstract}

Keywords: Health Protocol, Covid-19

\begin{abstract}
ABSTRAK
Kegiatan pegabdian kepada masyarakat ini bertujuan untuk mensosialisasikan dan memberikan edukasi mengenai pentingnya menerapkan protokol kesehatan sebagai upaya memutus mata rantai penyebaran covid-19. Adapun metode yang dilakukan berupa penyuluhan dan pemberian informasi mengenai pentingnya penerapan protokol kesehatan dan perilaku hidup bersih dengan rajin mencuci tangan dengan sabun, menggunakan masker ketika beraktivitas diluar rumah dan menjaga jarak aman ketika berada ditempat umum. Kegiatan ini dilaksanakan di Aula Kelurahan Ciputat Jalan Ki Hadjar Dewantara no. 7 Rt.001/006, Ciputat, Tangerang Selatan.Hasil menunjukkan bahwa setelah pelaksanaan kegiatan ini para peserta dari kelurahan Ciputat menjadi semakin mengetahui mengenai pentingnya menerapkan protokol kesehatan baik mengenai cara mencuci tangan dan menggunakan masker yang benar maupaun jarak aman agar terhindar dari penularan covid-19. Namun demikian,
\end{abstract}


kesadaran masyarakat sekitar terkait pentingnya menerapkan protokol kesehatan masih kurang khususnya terkait menjaga jarak aman. Selain itu, mobilitas masyarakat juga masih sulit untuk dikendalikan baik untuk bekerja maupun hanya sekedar pergi keluar rumah. Dengan adanya sosialisasi ini maka diharapkan para peserta dengan wewenangnya sebagai perangkat desa dapat menularkan pengetahuan dan pemahaman mereka kepada masyarakat khususnya warga Kelurahan Ciputat.

\section{Kata kunci : Protokol Kesehatan, Covid- 19}

\section{A. PENDAHULUAN}

Coronaviruses (CoV) merupakan bagian dari keluarga virus yang menyebabkan penyakit mulai dari flu hingga penyakit yang lebih berat seperti Middle East Respiratory Syndrome (MERS-Cov) and Severe Acute Respiratory Syndrome (SARS-CoV). Penyakit yang disebabkan virus corona, atau dikenal dengan COVID19, adalah jenis baru yang ditemukan pada tahun 2019 dan belum pernah diidentifikasi menyerang manusia sebelumnya (World Health Organization dalam Novriyanti. 2020). Jumlah kasus positif maupun yang meninggal akibat covid-19 terus meningkat dari waktu ke waktu semenjak tujuh bulan terakhir dan tersebar hampir di seluruh wilayah di Indonesia. Situasi virus covid-19 di Indonesia per 01 Oktober 2020 berjumlah 291.182 kasus positif, 218.487 kasus sembuh dan 10.856 kasus meninggal dunia akibat covid-19 (https://covid19.go.id). Berbagai upaya dilakukan pemerintah baik pusat maupun daerah dalam menangani kasus ini. Seperti kasus covid nasional yang terus mengalami kenaikan, Tangerang Selatan sebagai salah satu kota di Propinsi Banten juga terus megalami lonjakan kasus covid-19 dari waktu ke waktu. Pemerintah kota Tangerang Selatan melalui Satuan Gugus Tugas mengumumkan bahwa per 30 September 2020 secara akumulatif jumlah kasus psitif Covid-19 sebanyak 1.135 kasus.

Terus meningkatnya kasus Covid-19 di Propinsi Banten, termasuk diantara di Kota Tangerang Selatan dipengaruhi oleh beberapa faktor, diantaranya adalah karena semakin menurunnya kesadaran masyarakat untuk menjaga protokol kesehatan, mobilitas warga yang tidak terkontrol sehingga saling berakibat pada satu wilayah dengan wilayah lainnya. Disiplin menerapkan protokol kesehatan merupakan langkah preventif yang dapat dilakukan oleh setiap masyarakat untuk melindungi diri maupun keluarga dari penularan Covid-19. Protokol kesehatan diatur dalam KEMENKES RI No. HK.01. 07/MENKES/382/2020 tentang Protokol Kesehatan Bagi Masyarakat di Tempat Umum Dalam Rangka Pencegahan dan Pengendalian Corona Virus Disease 2019 (Covid-19).

Namun demikian angka kepatuhan masyarakat Tangerang Selatan terhadap disiplin penerapan protokol kesehatan yang masih dibawah angka ideal sementara penularan corona yang terus meningkat, maka menjadi penting untuk meningkatkan kesadaran masyarakat agar tidak abai terhadap protokol kesehatan. Kecamatan Ciputat menjadi wilayah ketiga kasus tertinggi di Tangsel dengan jumlah 130 kasus positif dan diantaranya 16 kasus tersebut ada di Kelurahan Ciputat. Sebagai salah satu wujud upaya kepedulian kami terhadapat permasalahan ini, Dosen Universitas Pamulang dan mahasiswa mengadakan kegiatan Pengabdian Kepada Masyarakat (PKM) bekerjasama dengan Kelurahan Ciputat untuk 
memberikan sosialisasi mengenai pentingnya Menerapkan Protokol Kesehatan Sebagai Upaya Memutus Mata Rantai Penyebaran Covid -19 di Kelurahan Ciputat.

\section{B. METODE PELAKSANAAN KEGIATAN}

Pengabdian kepada masyarakat ini dialakan selama dua hari pada tanggal 12-13 oktober 2020 yang bertempat di Kelurahan Ciputat, Jalan Ki Hajar Dewantara, Kecamatan Ciputat Kota Tangerang Selatan - Banten. Yang menjadi sasaran dalam kegiatan PKM ini adalah peserta dari Kelurahan Ciputat. Adapun metode dalam pelaksanaan kegiatan pengabdian ini meliputi:

1. Tahap Persiapan.

Pada tahap persiapan, kami melakukan survey awal ke lokasi yaitu Kelurahan Ciputat untuk menggali informasi mengenai perkembangan kasus Covid-19 di wilayah tersebut dan bagaimana tingkat pemahaman maupun kesadaran masyarakat terhadap penerapan protokol kesehatan sebagai upaya menekan penyebaran covid-19.

2. Tahap Pemberian Penyuluhan

Para peserta diberikan penyuluhan mengenai pentingnya menerapkan protokol kesehatan sebagai upaya memutus mata rantai penyebaran covid-19. Diuaraikan juga mengenai tata cara mencuci tangan yang benar, cara menggunakan masker yang benar dan diberikan pemahaman kepada peserta mengenai pentingnya menjaga jarak aman agar terhindar dari penularan covid-19. Pada kesempatan ini juga diberikan masker kepada para peserta.

3. Proses Tanya Jawab

Tahap ini bertujuan untuk memberikan kesempatan kepada peserta untuk menanyakan hal- hal yang mungkin belum mereka pahami khususnya terkait covid-19 maupun mengenai protocol kesehatan. Sehingga melalui proses ini dapat diketahui juga sejauh mana pemahaman peserta terhadap sosialisasi yang sudah disampaikan.

\section{HASIL DAN PEMBAHASAN}

Kegiatan sosialisasi ini dilakukan di aula Kelurahan Ciputat dan berlangsung selama 2 hari yaitu tanggal 12 dan 13 Oktober 2020 dan dihadiri oleh 15 orang yang menjadi peserta kagiatan. Semua peserta mengikuti kegiatan sosialisasi ini dengan baik karena manganggap bahwa informasi yang disampaikan dalam kegiatan ini sangat penting dan erat kaitannya dengan situasi pandemic yang terjadi saat ini.

Sosialisasi dilakukan dengan memberikan pemahaman mengenai pentingnya menerapkan protokol kesehatan yaitu dengan rajin mencuci tangan dengan sabun, selalu memakai masker ketika beraktivitas diluar rumah dan menjaga jarak aman ketika berada ditempat umum. Pada kesempatan ini juga diberikan edukasi mengenai bagaimana cara mencuci tangan yang benar. Selain itu para peserta juga diberikan masker secara gratis dan diberikan pemahaman mengenai bagaimana cara menggunakan masker yang benar.

Hasil kegiatan ini menunjukkan bahwa setelah pelaksanaan Pengabdian Kepada Masyarakat (PKM), para peserta dari kelurahan Ciputat sudah mengetahui mengenai pentingnya menerapkan protokol kesehatan baik mengenai cara mencuci tangan dan menggunakan masker yang benar maupaun jarak aman agar terhindar dari penularan covid- 


\section{"Hedixasi pyl|}

P-ISSN 2716-3652 E-ISSN 2723-1003

DEDIKASI PKM UNPAM

Vol. 2, No. 2, Mei, 2021, Hal (169-174)

@Prodi Manajemen Fakultas Ekonomi Universitas Pamulang

19. Namun demikian pada prakteknya ternyata kesadaran masyarakat sekitar terkait pentingnya menerapkan protokol kesehatan masih kurang khususnya terkait menjaga jarak aman. Selain itu, mobilitas masyarakat juga masih sulit untuk dikendalikan baik untuk bekerja maupun hanya sekedar pergi keluar rumah. Dengan adanya sosialisasi ini maka diharapkan para peserta dengan wewenangnya sebagai perangkat desa dapat menularkan pengetahuan dan pemahaman mereka kepada masyarakat khususnya warga Kelurahan Ciputat. Berikut gambar foto pelaksanaan pengabdian kepada masyarakat:

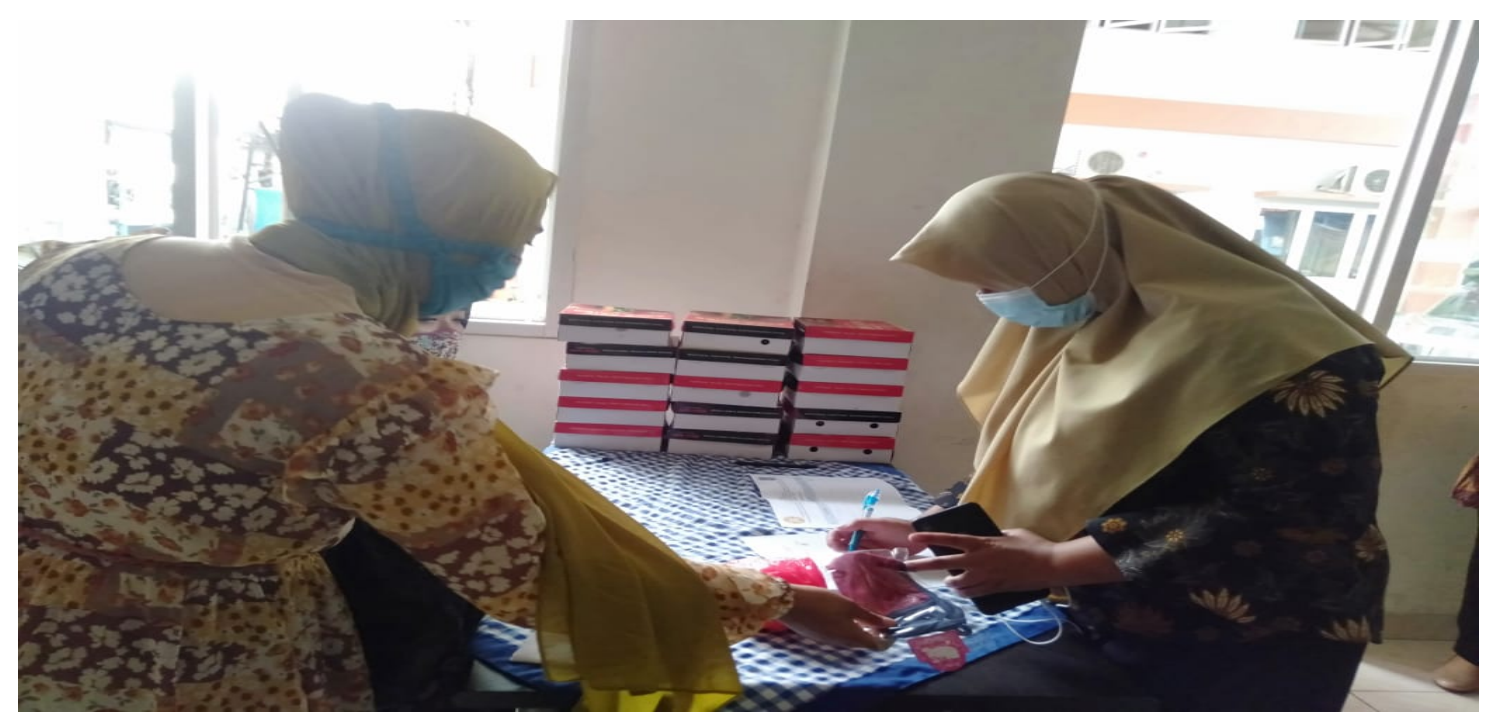

Gambar 1 Proses Pendaftaran/Absensi Peserta

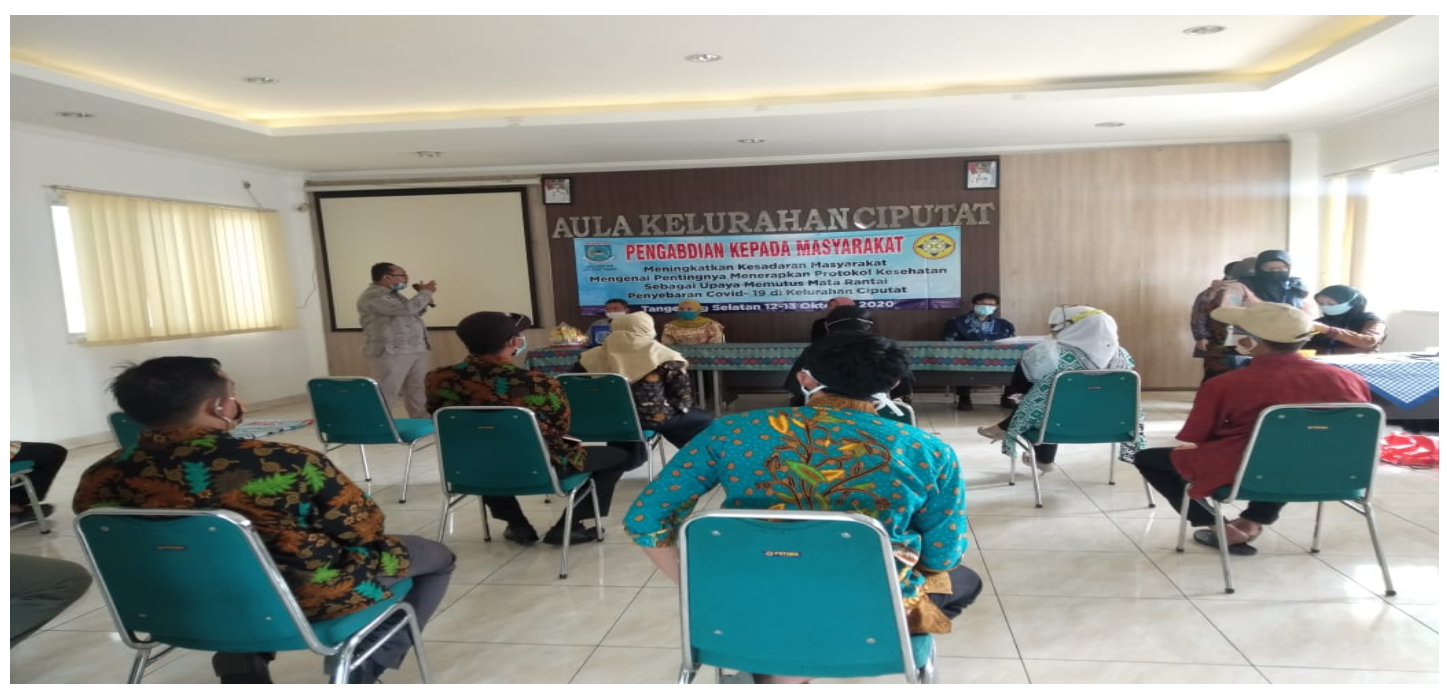

Gambar 2 Pemberian materi / penyuluhan tentang Covid-19 yang disampaikan oleh Dosen Universitas Pamulang yaitu Dede Abdurohman S.E, M.M 


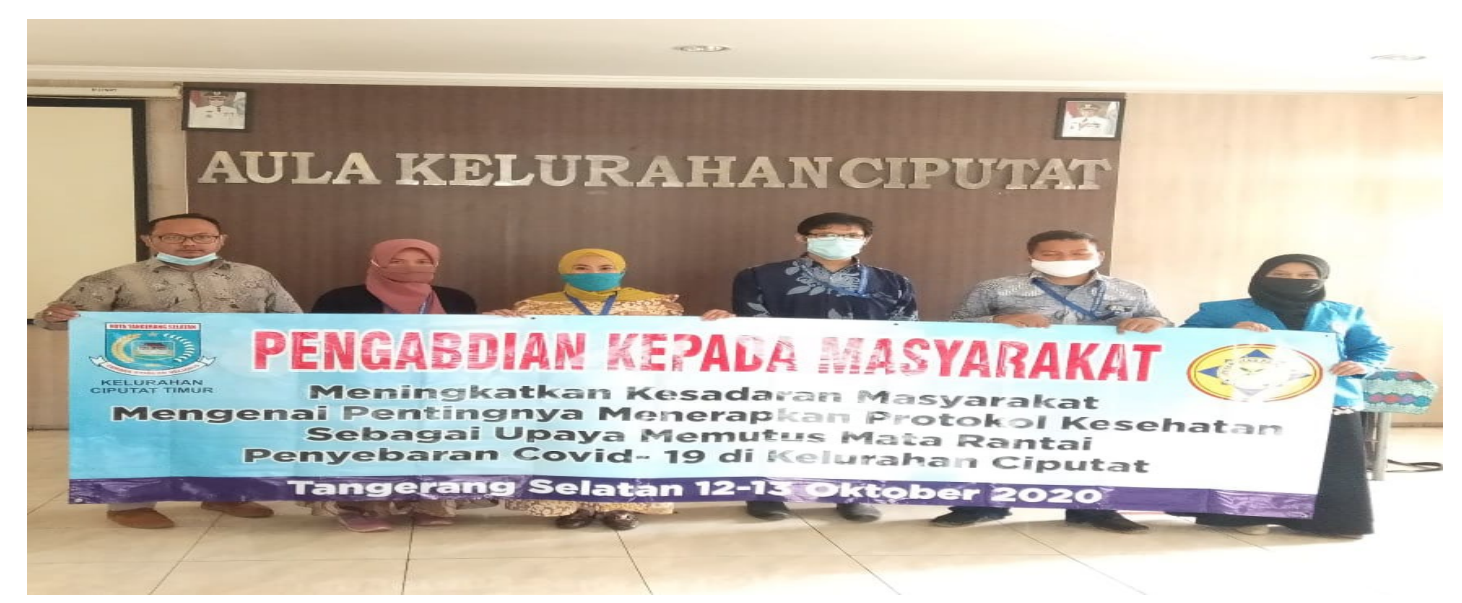

Gambar 3 Foto team Pengabdian kepada masyarakat

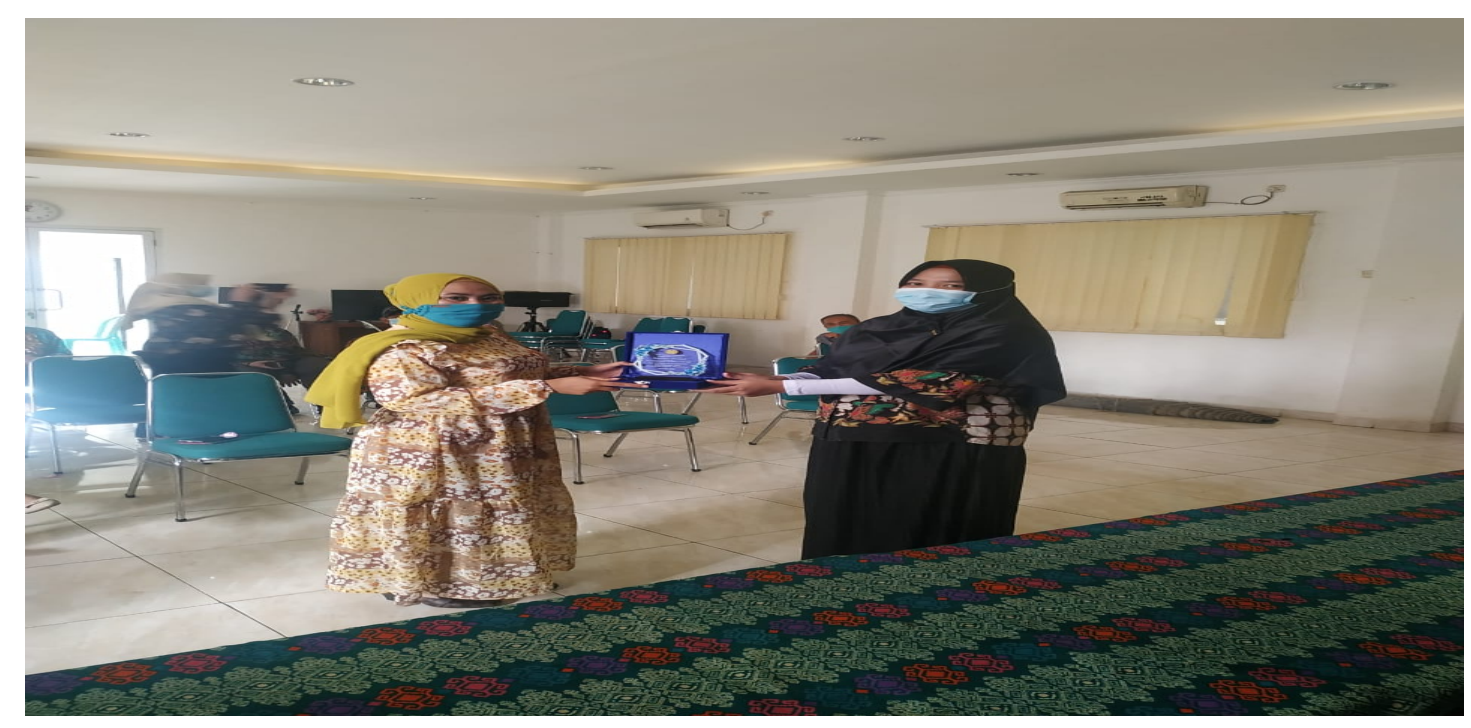

Gambar 4. Penyerahan Piagam

\section{KESIMPULAN DAN SARAN}

\section{Kesimpulan}

Adapaun kesimpulan yang dapat diambil dari kegiatan Pengabdian Kepada Masyarakat (PKM) ini adalah para peserta dari kelurahan Ciputat sudah mengetahui mengenai pentingnya menerapkan protokol kesehatan, namun demikian kesadaran masyarakat sekitar terkait pentingnya menerapkan protokol kesehatan masih kurang khususnya terkait menjaga jarak aman. Selain itu, mobilitas masyarakat juga masih sulit untuk dikendalikan. Dengan adanya sosialisasi melalui kegiatan Pengabdian Kepada Masayarakat (PKM) ini maka diharapkan para peserta dengan wewenangnya sebagai perangkat desa dapat menularkan pengetahuan dan pemahaman mereka kepada masyarakat khususnya warga Kelurahan Ciputat. 


\section{Saran}

Adapun saran yang dapat direkomendasikan adalah agar kegiatan sosialisasi dan edukasi terkait pentingnya penerapan protokol kesehatan dilakukan secara lebih intens lagi agar kesadaran masyarakat khususnya warga Kelurahan Ciputat dapat semakin meningkat sehingga kasus covid-19 di wilayah tersebut dapat dikendalikan

\section{DAFTAR PUSTAKA}

Lubis, Novriyanti, dkk. 2020. "Gerakan Desa Sadar Bahaya Covid 19 Pengabdian Pada Masayrakat Desa Cilawu Kabupaten Garut". Jurnal Kretaif Pengabdian Kepada Masyarakat, P-ISSN 2615-0921 E-ISSN: 2622-6030 Vol 3, No. 2.

Sembiring, Sembiring dan Dewi E.S. 2020. "Sosialisasi Penerapan Protokol Kesehatan di Masa Pandemi Dengan Pembagian Masker Kesehatan Kepada Para Pedagang dan Pengunjung Pasar Tradisional Pajak Sore Padang Bulan”. Jurnal Abdimas Mutiara Volume. 1 No. 2.

KEMENKES RI NOMOR HK.01.07/MENKES/382/2020 tentang Protokol Kesehatan Bagi Masyarakat di Tempat Umum Dalam Rangka Pencegahan dan Pengendalian Corona Virus Disease 2019 (Covid-19).

https://covid19.go.id

http://hukor.kemkes.go.id

https://kaltim.tribunnews.com/2020/10/01/kabar-bahagia-bio-farma-ungkap-perkembanganuji-klinis-vaksin-covid-19-kapan-siap-digunakan.

https://kelciputat.blogspot.com/2012/09/profil-kelurahan-ciputat.html

https://megapolitan.kompas.com/read/2020/10/01/09450761/sebaran-kasus-covid-19-ditangsel-tiga-kelurahan-di-pamulang-paling?page $=2$

https://www.cnnindonesia.com/nasional/20200906220449-20-543394/covid-meningkatbanten-berlakukan-psbb-seluruh-wilayah

https://tirto.id/cara-cuci-tangan-yang-benar-untuk-cegah-virus-corona-covid-19-eCPj

https://kabar24.bisnis.com/read/20201001/15/1299298/penting-nih-ini-tips-menjaga-jarakagar-terhindar-dari-covid-19 